\title{
Using of Microscopy in Optimization of the Ti-Al-Si Alloys Preparation by Powder Metal- lurgy
}

Anna Knaislová, Pavel Novák, Kateřina Nová

Department of Metals and Corrosion Engineering, University of Chemistry and Technology Prague. Technická 5, 16628 Prague. Czech Republic. E-mail: knaisloa@vscht.cz

\begin{abstract}
Automotive and aerospace industries are searching for new high-temperature structural materials with improved properties (especially resistance to oxidation, thermal stability and mechanical properties) in combination with low density. Ti-Al-Si alloys fulfill these requirements, but they are very difficult to prepare. In this work, we propose technology including Self-propagating High-temperature Synthesis (SHS), milling and following consolidation by Spark Plasma Sintering. The technology has been tested on the TiAl20Si20 alloy. Special attention was paid to microstructure and phase composition, and their changes depending on the processing stage.
\end{abstract}

Keywords: Intermetallics, Powder Metallurgy, Self-propagating High-temperature Synthesis, Spark Plasma Sintering

\section{Acknowledgement}

This research was financially supported by Czech Science Foundation, project No. P108/12/G043.

\section{References}

[1] NOVÁK, P., PRŮŠA, F., ŠERÁK, J., VOJTĚCH, D., MICHALCOVÁ, A. (2009). Oxidation resistance and thermal stability of Ti-Al-Si alloys produced by reactive sintering. In: Metal.

[2] GUAN, Z. Q., PFULLMANN, T., OEHRING, M., BORMANN, R. (1997). Phase formation during ball milling and subsequent thermal decomposition of Ti-Al-Si powder blends. In: Journal of Alloys and Compounds, 252, 12, pp. 245-251.

[3] WU, J. S., BEAVEN, P.A.,WAGNER, R. (1990). The Ti3(Al, Si) + Ti5(Si, Al)3 Eutectic Reaction in the Ti-AlSi system. In: Scripta Metallurgica et Materialia, 24, 1, pp. 207-212.

[4] NOVÁK, P., VOJTĚCH, D., ŠERÁK, J., KUBÁSEK, J., PRŮŠA, F., KNOTEK, V., MICHALCOVÁ, A., NOVÁK, M. (2009). Syntéza intermediálních fází systému Ti-Al-Si metodou reaktivní sintrace. In: Chemické listy $103,1022-1026$.

[5] ZEMČÍK, L., DLOUHÝ, A., KRÓL, S.,PRAŻMOWSKIC, M. (2005). Vacuum Metallurgy of TiAl Intermetallics. In: Metal.

[6] NOVÁK, P., MICHALCOVÁ, A., MAREK, I., VODĚROVÁ, M.,VOJTĚCH, D. (2012). Possibilities of the observation of chemical reactions during the preparation of intermetallics by reactive sintering. In: Manufacturing technology, Vol. 12, No. 13, pp. 197-201.

[7] VYSTRČIL, J., NOVÁK, P.,MICHALCOVÁ, A. (2015). Preparation of Ultra-Fine Grained Alloys Based on FeAl-Si And Ti-Al-Si Intermetallic Compounds by Powder Metallurgy Using the Mechanical Alloying. In: Manufacturing Technology, Vol. 15, No. 2, pp. 238-242.

[8] SUÁREZ, M., FERNÁNDEZ, A., MENÉNDEZ, J.L., TORRECILLAS, R., KESSEL, H.U., HENNICKE, J., KIRCHNER, R.,KESSEL, T. (2013). Challenges and Opportunities for Spark Plasma Sintering: A Key Technology for a New Generation of Materials. In: InTech.

[9] ZHANG, Z.-H., LIU, Z.-F., LU, J.-F., SHEN, X.-B., WANG, F.-C.,WANG, Y.-D. (2014). The sintering mechanism in spark plasma sintering - Proof of the occurrence of spark discharge. In: Scripta Materialia, 81, 56-59.

[10] LIU, Y.,LIU, W. (2007). Mechanical alloying and spark plasma sintering of the intermetallic compound Ti50A150. In: Journal of Alloys and Compounds, 440, 1-2, pp. 154-157.

[11] NOVÁK, P., MICHALCOVÁ, A., ŠERÁK, J., VOJTĚCH, D., FABIÁN, T., RANDÁKOVÁ, S., PRŮŠA, F., KNOTEK, V., NOVÁK, M. (2009). Preparation of Ti-Al-Si alloys by reactive sintering. In: Journal of Alloys and Compounds, 470, 1-2, pp. 123-126. 